(C) 2021, The Authors. Published by Elsevier Inc. and Fass Inc. on behalf of the American Dairy Science Association ${ }^{\circledR}$. This is an open access article under the CC BY-NC-ND license (http://creativecommons.org/licenses/by-nc-nd/4.0/).

\title{
Intestinal adaptations to energy source of milk replacer in neonatal dairy calves
}

\author{
A. C. Welboren, ${ }^{1} \odot$ B. Hatew, ${ }^{2} \odot$ J. B. Renaud, ${ }^{3}$ L. N. Leal, ${ }^{4}{ }^{\oplus}$ J. Martín-Tereso, ${ }^{4} \odot$ and M. A. Steele ${ }^{1,2 *} \odot$ \\ ${ }^{1}$ Department of Animal Biosciences, University of Guelph, Guelph, ON, Canada, N1G 2W1 \\ ${ }^{2}$ Department of Agricultural, Food and Nutritional Science, University of Alberta, Edmonton, AB, Canada, T6G 2P5 \\ ${ }^{3}$ London Research and Development Centre, Agriculture and Agri-Food Canada, London, ON, Canada, N5V 4T3 \\ ${ }^{4}$ Trouw Nutrition Research and Development, PO Box 299, 3800 AG, Amersfoort, the Netherlands
}

\begin{abstract}
Most milk replacers (MR) contain more lactose compared with whole milk, which, when fed at a large meal size, could influence gut barrier function in calves. This study evaluated how replacing lactose in MR with fat (on a wt/wt basis) affects intestinal histomorphology and permeability in neonatal dairy calves. Thirty-four Holstein-Friesian bull calves were blocked by dam parity and randomly assigned to 1 of 2 treatments $(\mathrm{n}=$ 17): a high-lactose (46.1\% lactose, $18.0 \%$ crude fat, and $23.9 \%$ crude protein of dry matter) or a high-fat MR (HF; $39.9 \%$ lactose, $24.6 \%$ crude fat, and $24.0 \%$ crude protein of dry matter). Calves were individually housed and fed pooled colostrum at $1.5 \mathrm{~h}$ and $12 \mathrm{~h}$ postnatally, at 18 and $9 \%$ of metabolic body weight $\left(\mathrm{BW}^{0.75}\right)$, respectively. From $24 \mathrm{~h}$ postnatally until the end of the study (d 7), calves were transitioned to be fed MR (prepared at $15 \%$ solids) at $18 \%$ of $\mathrm{BW}^{0.75}$ twice daily at 0700 and $1900 \mathrm{~h}$. During postprandial sampling on d 6, intestinal permeability was assessed by mixing lactulose $\left(1.03 \mathrm{~g} / \mathrm{kg}\right.$ of $\left.\mathrm{BW}^{0.75}\right)$ and D-mannitol (0.31 $\mathrm{g} / \mathrm{kg}$ of $\left.\mathrm{BW}^{0.75}\right)$ into the morning meal without altering total meal volume. Sequential blood samples were collected via jugular catheter, and total urine was collected for $12 \mathrm{~h}$ to measure the marker content. Calves were euthanized $3 \mathrm{~h}$ after the morning meal on $\mathrm{d} 7$, and gastrointestinal tract tissues and digesta were collected for analysis of histomorphology, digesta osmolality, and gene expression. The empty gastrointestinal tracts of HF calves were heavier, although length did not differ and differences in histomorphology were minor. Digesta osmolality changed along the tract without differences between treatments. Plasma lactulose was greater in $\mathrm{HF}$, although plasma D-mannitol and the recovery of
\end{abstract}

Received March 24, 2021.

Accepted July 7, 2021.

*Corresponding author: masteele@uoguelph.ca both markers in urine were unaffected. No significant differences were detected in gene expression, although HF calves tended to have lower expression of TJP1 and $C L D N 2$ and higher expression of proinflammatory cytokine $I L 1 B$ in ileum tissue. In conclusion, partially replacing lactose in MR with fat resulted in a heavier and more permeable gut, with minor histomorphological differences.

Key words: lactose, fat, gastrointestinal permeability, osmolality, histomorphology

\section{INTRODUCTION}

Recently, calf research has focused on feeding elevated planes of milk or milk replacer (MR) to improve preweaning growth performance (Khan et al., 2011; Soberon and Van Amburgh, 2013), with little consideration for the macronutrient composition of the liquid feed. Relative to whole milk, MR generally contains more lactose (approximately 43 vs. 37\% of DM) and less fat (21 vs. $28 \%$ of DM; Lee et al., 2009; Pantophlet et al., 2016; Amado et al., 2019). Feeding greater amounts of a high-lactose MR could potentially overload the gastrointestinal tract (GIT) with lactose. Undigested and unabsorbed lactose from the meal accumulates in the gut lumen, which increases gut lumen osmolality (Hof, 1980). This reduces the osmotic gradient for water absorption by intestinal epithelia (Jodal and Lundgren, 1986), potentially resulting in osmotic diarrhea. Furthermore, an increase in GIT lumen osmolality may increase gastrointestinal permeability. Wilms et al. (2019) found that MR osmolality is positively correlated with gastrointestinal permeability, and it has been suggested that exposure to high osmotic pressure could cause structural damage to tight junctions (Kameda et al., 1968). Therefore, it is possible that oversupplying lactose contributes to the prevalence of digestive disturbance on dairy farms that causes high rates of morbidity ( $56 \%$ of calves reported ill; Urie et al., 2018). The osmotic threshold at which calves develop loose feces or diarrhea (i.e., $<8.9$ and $6.4 \%$ of 
$\mathrm{DM}$, respectively) was determined to be $10 \mathrm{~g}$ of hexose equivalent/kg of BW per day (Hof, 1980). For a $45-\mathrm{kg}$ calf, this threshold would be reached when ingesting approximately $7 \mathrm{~L}$ of $\mathrm{MR}$ (containing $43 \%$ lactose and fed at $150 \mathrm{~g} / \mathrm{L}$ ), a common feeding level nowadays. Therefore, it is of great interest to evaluate how macronutrient composition affects the intestinal development and function of calves fed large quantities of MR.

Typically, excess content of lactose in MR is the result of its low content of fat. Milk fat content is crucial for delivering energy and regulation of body temperature (Young, 1976; Urie et al., 2018). Furthermore, adipose development affects newborn survival (Louveau et al., 2016). Recent studies have shown that increasing the fat content of MR from 17 to $23 \%$ of $\mathrm{DM}$ and from 21 to $31 \%$ of DM by reducing the lactose content reduced the number of therapeutic interventions required (mainly respiratory) and the number of calves with loose feces from birth until approximately $10 \mathrm{wk}$ of age (Amado et al., 2019; Berends et al., 2020). Furthermore, Urie et al. (2018) evaluated calf feeding practices across the United States and found that the predicted mortality risk for calves receiving less than $150 \mathrm{~g}$ of fat per day from the liquid diet was $9 \%$, compared with $3 \%$ for calves fed more than $150 \mathrm{~g} / \mathrm{d}$. According to the authors, calves ingesting an insufficient amount of fat have less energy available to fight infections and are more likely to die during the preweaning period. In addition, increasing dietary fat promoted GIT growth in rats (Maxton et al., 1989). Potentially, dietary fat can promote GIT function and growth by stimulating secretion of gut peptides such as cholecystokinin or glucagon-like peptide- 1 and 2 via receptors commonly referred to as nutrient-sensing receptors (Rasoamanana et al., 2012; Furness et al., 2013). These nutrientsensing receptors, mostly located on enteroendocrine cells throughout the entire GIT, sense the GIT lumen continuously for nutrients, pathogenic microorganisms, toxins, and other components, and subsequently activate the enteroendocrine system, the nervous system, the GIT immune system, and the nonimmune defense system of the GIT (Furness et al., 2013).

Despite the obvious difference in macronutrient composition between whole milk and most MR, it is currently unknown how this difference influences intestinal development and function in dairy calves. We hypothesized that a high-fat MR would stimulate GIT development and induce adaptations by activating nutrient-sensing receptors in the intestinal epithelium. We also hypothesized that a high-fat MR would reduce gastrointestinal permeability. The objective of this study was to evaluate the effects of partially replacing lactose in MR with fat on GIT weight, gastrointestinal histomorphology, gastrointestinal permeability, and expression of genes coding for nutrient sensing receptors, nutrient transporters, tight junction proteins, and cytokines in neonatal calves.

\section{MATERIALS AND METHODS}

The study was conducted at the Dairy Research and Technology Centre of the University of Alberta (Edmonton, AB, Canada) from September 2017 to April 2018. Animal procedures complied with the guidelines of the Canadian Council of Animal Care (CCAC, 1993) and were approved by the Animal Care and Use Committee of the University of Alberta (AUP00002418).

\section{Animals, Housing, and Treatments}

This study was conducted in the first week of life to study the calf's initial response to milk feeding before it potentially adapts to the macronutrient supply. Furthermore, morbidity in dairy calves is particularly high during the first 2 wk of life (Urie et al., 2018), which demonstrates the need to investigate and improve our understanding of the neonatal phase. Using the POWER procedure of SAS software (power $=0.8$; $\alpha=0.05$; version 9.4 , SAS Institute Inc.), the number of animals required to detect a difference in recovery of gastrointestinal permeability markers was 14 per treatment group based on means and standard deviations (SD) of a previous study with calves (Amado et al., 2019). Taking into account potential losses of calves during the study, 34 Holstein bull calves with an average birth BW $( \pm \mathrm{SEM})$ of $43.2 \pm 0.81 \mathrm{~kg}$ were included in the study. Calves were separated from the dam approximately 15 min after birth, weighed using an electronic scale (SW300, Digi-Star LLC) and moved to individual pens $(122 \times 183 \mathrm{~cm}$; width $\times$ length $)$ that were bedded with shavings and straw. Before occupation, pens were cleaned and disinfected using a 1\% Virkon solution (Lanxess), rinsed with water, and left to dry. After they were moved to individual pens, calves were dried and stimulated with clean towels for approximately $10 \mathrm{~min}$. At $1.5 \mathrm{~h}$ after birth, calves were bottle-fed pooled colostrum (2.8\% lactose, $4.5 \%$ crude fat, and $12.6 \% \mathrm{CP} ; 63.9 \mathrm{~g} / \mathrm{L}$ of IgG; colostrum was pooled and frozen by Saskatoon Colostrum Company Ltd., Saskatoon, SK, Canada) at $18.1 \%$ of their metabolic BW $\left(\mathbf{B W}^{\mathbf{0 . 7 5}}\right)$. A second meal $\left(9.1 \% \mathrm{BW}^{0.75}\right)$ of pooled colostrum was offered by bottle $12 \mathrm{~h}$ after birth. Before feeding, colostrum was thawed and warmed to a temperature of $39^{\circ} \mathrm{C}$ using a water bath. If more than $25 \%$ of a colostrum meal remained, the remainder was drenched using an esophageal tube feeder. 
In a randomized complete block design, calves were blocked by dam parity and randomly assigned to 1 of 2 treatments: a high-lactose (HL; $46.1 \%$ lactose, $18.0 \%$ crude fat, and $23.9 \% \mathrm{CP}$ of $\mathrm{DM} ; \mathrm{n}=17$; birth $\mathrm{BW}=$ $44.3 \pm 1.03 \mathrm{~kg})$ or a high-fat MR (HF; $39.9 \%$ lactose, $24.6 \%$ crude fat, and $24.0 \% \mathrm{CP}$ of $\mathrm{DM} ; \mathrm{n}=17$; birth $\mathrm{BW}=42.3 \pm 1.19 \mathrm{~kg}$; Sloten B.V., Trouw Nutrition). Ingredients and nutrient composition of the MR used in the present study (analyzed by Masterlab, Trouw Nutrition, Boxmeer, the Netherlands) are presented in Table 1. The MR was prepared at $15 \%$ solids and bottle-fed at $18.1 \%$ of $\mathrm{BW}^{0.75}$. The assigned MR was fed $24 \mathrm{~h}$ after birth, and thereafter calves were adjusted to being fed twice daily at 0700 and $1900 \mathrm{~h}$. On d 4, calves were reweighed before the morning meal, and meal size was adjusted accordingly. Intake and refusal of MR was recorded for each meal until d 7 after birth. At all times, fresh water was available ad libitum, and intake was recorded daily. The calves did not have access to solid feed.

\section{Gastrointestinal Permeability}

On d 6, lactulose $\left(1.03 \mathrm{~g} / \mathrm{kg}\right.$ of $\mathrm{BW}^{0.75} ; 427584$, MilliporeSigma) and D-mannitol $\left(0.31 \mathrm{~g} / \mathrm{kg}\right.$ of $\mathrm{BW}^{0.75}$; 1.05982, MilliporeSigma) were dissolved in $100 \mathrm{~mL}$ of warm water and added to the morning MR meal without altering total meal volume. Total urine was collected between 0700 and $1900 \mathrm{~h}$ by attaching a urine collection bag (Urine Bag Romed 2 L, Pontos) to the underside of the calf using medical adhesive spray and tape. All study pens contained a wooden platform to elevate the calves, which were tethered to the front gate, to facilitate urine flow from the bag into a bucket. At the end of the sampling day, the urine collected was homogenized, and a subsample was transferred to a 50-mL Falcon tube and frozen at $-20^{\circ} \mathrm{C}$ until analysis. Sequential blood samples were collected via a catheter (Terumo IV Catheter Surflash $16 \mathrm{~g} \times 2$ in.) inserted into the jugular vein. Heparinized saline $(20 \mathrm{IU} / \mathrm{mL}$, Fresenius Kabi) was used to flush the catheter line. Blood was centrifuged at $3,000 \times g$ at $4^{\circ} \mathrm{C}$ for $20 \mathrm{~min}$, and supernatant was transferred into microcentrifuge tubes and frozen at $-20^{\circ} \mathrm{C}$ until analysis.

Before lactulose and D-mannitol analysis, urine (10.7 $\mu \mathrm{L}+42.6 \mu \mathrm{L}$ of double-distilled $\mathrm{H}_{2} \mathrm{O}$ ) and plasma (53.3 $\mu \mathrm{L})$ samples were purified in duplicate by adding 107 $\mu \mathrm{L}$ of $10 \mathrm{mM}$ ammonium formate in $90 \%$ acetonitrile and $4 \mu \mathrm{L}$ of internal standards $\left[{ }^{13} \mathrm{C}_{6}\right.$ mannitol $(75 \mu \mathrm{g} /$ $\mu \mathrm{L})$, Cambridge Isotope Laboratories Inc.; and ${ }^{13} \mathrm{C}_{12}$ lactulose $(75 \mu \mathrm{g} / \mu \mathrm{L})$, Omicron Biochemicals Inc.] to each vial, and subsequently centrifuging the samples at
Table 1. Ingredients and nutrient composition of the milk replacers fed to calves in the first week of life ${ }^{1}(\mathrm{n}=34)$

\begin{tabular}{lcc}
\hline Item & $\begin{array}{c}\text { High } \\
\text { lactose }\end{array}$ & $\begin{array}{c}\text { High } \\
\text { fat }\end{array}$ \\
\hline Ingredient (\%) & & \\
Skim milk powder & 29.5 & 29.5 \\
Fat blend (palm and coconut oil, 2:1) & 16.7 & 22.6 \\
Delactosed whey & 10.5 & 13.2 \\
Whey powder & 30.1 & 14.7 \\
Whey permeate powder & 3.0 & 7.3 \\
Whey protein concentrate & 4.8 & 7.0 \\
Hydrolyzed wheat protein & 4.0 & 4.1 \\
Premix & 1.5 & 1.7 \\
Nutrient (\% of DM unless otherwise noted) & & \\
DM (\%) & 97.5 & 97.5 \\
Lactose & 46.1 & 39.9 \\
Crude fat & 18.0 & 24.6 \\
CP & 23.9 & 24.0 \\
Crude ash ${ }^{2}$ & 7.9 & 7.7 \\
ME (Mcal/kg of DM) & 4.23 & 4.49 \\
Osmolality (mOsm/kg) & 489.5 & 457.0 \\
\hline
\end{tabular}

${ }^{1}$ Milk replacer (15\% solids) was fed at $18 \%$ of metabolic body weight twice daily from $24 \mathrm{~h}$ until $7 \mathrm{~d}$ of age.

${ }^{2}$ Milk replacers were formulated to contain 17.0 vs. 16.5 , 13.0 vs. 12.4 , 8.0 vs. 8.0 , and 7.3 vs. $7.1 \mathrm{~g} / \mathrm{kg}$ of $\mathrm{DM}$ of $\mathrm{K}, \mathrm{Cl}, \mathrm{Ca}$, and $\mathrm{P}$ in the highlactose and high-fat milk replacer, respectively.

$10,000 \times g$ at $4^{\circ} \mathrm{C}$ for 10 min to separate the soluble and insoluble fractions. The supernatant (soluble fraction) was collected. All samples were analyzed by a Thermo Vanquish Duo Tandem UHPLC System coupled to a TSQ Altis triple quadrupole mass spectrometer (Thermo Fisher Scientific). Samples were stored in an autosampler at $10^{\circ} \mathrm{C}$, and $3 \mu \mathrm{L}$ was injected onto 1 of 2 Agilent Poroshell 120 HILIC-Z (PEEK lined $100 \times$ $2.1 \mathrm{~mm} ; 2.7 \mu \mathrm{m})$ maintained at $45^{\circ} \mathrm{C}$ with a flow rate of $300 \mu \mathrm{L} / \mathrm{min}$. Mobile phase A (10 $\mathrm{m} M$ ammonium formate, $90 \%$ acetonitrile; Optima LC-MS grade) was held at $100 \%$ for $1.25 \mathrm{~min}$. Mobile phase B (10 $\mathrm{mM}$ $\mathrm{H}_{2} \mathrm{O}$; Optima LC-MS grade) was then increased to $60 \%$ over $1.0 \mathrm{~min}$ and held for $4.25 \mathrm{~min}$ before returning to $0 \%$ over $0.25 \mathrm{~min}$. While analytes were being resolved on one column, the second column was re-equilibrated for $7 \mathrm{~min}$ at $300 \mu \mathrm{L} / \mathrm{min}$, mobile phase $\mathrm{A}$, in preparation for the subsequent injection. The OptaMax NG H-ESI source was operated in negative ionization mode source with capillary voltage of $4.4 \mathrm{kV}$, an ion transfer tube temperature of $300^{\circ} \mathrm{C}$, and vaporizer temperature of $210^{\circ} \mathrm{C}$. The sheath, auxiliary, and sweep gases were set to 40,15 , and 1 arbitrary units, respectively. DMannitol, lactulose, and their corresponding internal standards were monitored using the settings listed in Table 2. Quantification was performed in Thermo TraceFinder 5.0 with $1 / \mathrm{x}$ weighting. The method detection limits for both analytes were $150 \mathrm{ng} / \mathrm{mL}$. Recovery of the markers in urine as percentage of the oral 
dose and plasma content of the markers was used as an indicator of gastrointestinal permeability.

\section{Postmortem Analysis}

Calves were euthanized $3 \mathrm{~h}$ after the morning meal on $\mathrm{d} 7$ to collect tissues from several segments of the GIT. Pentobarbital was infused (Euthanyl, Vetoquinol) at $0.125 \mathrm{~mL} / \mathrm{kg}$ of BW to achieve a surgical plane of anesthesia, after which the calf was euthanized and exsanguinated. The esophagus and rectum were tied using zip-ties to prevent contents from flowing out when the entire GIT was taken out and placed on a surgical table. Each segment of the GIT was emptied, weighed, and measured for length. The duodenum sample was taken $10 \mathrm{~cm}$ distal to the pyloric sphincter. The proximal jejunum sample was taken $100 \mathrm{~cm}$ distal to the duodenum sampling site. The distal jejunum sample was collected $30 \mathrm{~cm}$ proximal to the collateral branch of the cranial mesentery artery. The ileum sample was collected $30 \mathrm{~cm}$ proximal to the ileocecal junction, and the colon sample was collected $30 \mathrm{~cm}$ distal to the ileocecal junction (Malmuthuge et al., 2015). Zip-ties were placed on each end of the sample so that a subsample of digesta could be collected; the subsample was then snap frozen in liquid nitrogen and stored at $-80^{\circ} \mathrm{C}$ until analysis. The tissue sample was cut longitudinally and washed with sterile PBS. A cross section was fixed in $10 \%$ buffered formalin solution (4\% formaldehyde; Fisher Scientific), and another cross section was snap frozen in liquid nitrogen, after which the samples were stored at $-80^{\circ} \mathrm{C}$ until analysis.

\section{Digesta Osmolality}

Frozen digesta was thawed in a water bath at $37^{\circ} \mathrm{C}$, since a slow thawing process $\left(\right.$ at $\left.7^{\circ} \mathrm{C}\right)$ could increase osmolality (Seifarth et al., 2004). The sample was then mixed using a vortex, and osmolality was measured in duplicate based on freezing point depression with a micro-osmometer (model 3300, Advanced Instruments). The coefficient of variation across all samples from all segments was $0.62 \%$. The osmometer was cleaned between samples according to the user guide and calibrated at the beginning of each measuring day.

\section{Histomorphology}

The fixed intestinal tissues were embedded in paraffin and subsequently processed onto glass slides and stained with a hematoxylin and eosin stain (HistoCore Alberta Diabetes Institute, University of Alberta, Edmonton, Canada). Images were captured using a Leica ICC50W microscope at $40 \times$ magnification, connected to the Leica Airlab app (Leica Microsystems). Measurements were performed using ImageJ software (ImageJ 1.46r, National Institutes of Health). For each segment, 10 intact villi attached to the submucosa (approximately 4 images) were selected and measured per calf. The measurements included villus height (from the tip of the villus to the villus:crypt interface), villus width (at mid-villus height), crypt depth (from the villus: crypt interface to the muscularis mucosa), crypt width (the opening between villi at the villus:crypt interface level), and thickness of muscularis externa (inner circular and outer longitudinal muscle layers). Two trained research assistants who were unaware of the treatments performed the measurements. The measurements were averaged per calf and redone in case the research assistants found inconsistent results. Surface area index was calculated according to Kisielinski et al. (2002), who estimated absorptive surface area in rats.

\section{Quantitative Real-Time PCR}

Frozen tissue of proximal jejunum and ileum was ground in liquid nitrogen using a mortar and pestle. RNA was extracted using the PureLink RNA Mini Kit (Invitrogen). Briefly, $1 \mathrm{~mL}$ of TRIzol was added to 50 to $100 \mathrm{mg}$ of ground tissue, after which the sample was homogenized using a vortex. Then, RNA was extracted and precipitated by adding chloroform followed by $70 \%$ ethanol to the tissue homogenate and collected using a Spin Cartridge (included in the kit). The samples were treated with a DNase mixture (containing DNase I Reaction Buffer, RNase-free water and DNase I; Thermo

Table 2. Instrumental conditions for UHPLC-MS/MS analyses of lactulose and D-mannitol in urine and plasma of dairy calves to estimate gastrointestinal permeability ${ }^{1}$

\begin{tabular}{llcccc}
\hline Analyte & Ion type & RT $(\min )$ & Precursor $m / z$ & Quantifier $m / z(\mathrm{CE})$ & Qualifier $m / z(\mathrm{CE})$ \\
\hline Mannitol & {$[\mathrm{M}-\mathrm{H}]^{-}$} & 3.4 & 181.1 & $89(14)$ & $101(14)$ \\
${ }^{13} C_{6}$ mannitol & {$[\mathrm{M}-\mathrm{H}]^{-}$} & 3.4 & 187.1 & $92(14)$ & $161(12)$ \\
${ }^{13} C_{12}$ lactulose & {$[\mathrm{M}+\mathrm{HCOO}]^{-}$} & 3.6 & 387.1 & $167.1(12)$ & $179.1(12)$ \\
\hline
\end{tabular}

${ }^{1} \mathrm{RT}=$ retention time; $\mathrm{CE}=$ collision energy $(\mathrm{V})$. Italicized analytes are internal standards. 
Fisher Scientific) to remove any residual DNA. The Spin Cartridge was washed with wash buffers, and RNA was dissolved in RNase-free water. The RNA quantity and integrity number were measured using UV-visible spectroscopy (Nanodrop One Microvolume, Thermo Fisher Scientific) and electrophoresis (TapeStation, Agilent Technologies), respectively. The average RNA integrity number was $9.2 \pm 0.03(\mathrm{SE})$ and $9.6 \pm 0.04$ for proximal jejunum and ileum tissue, respectively. Then, $1 \mu \mathrm{g}$ of RNA was used to generate cDNA (HighCapacity cDNA Reverse Transcription Kit, Applied Biosystems), which was analyzed for the expression of genes encoding several nutrient sensing receptors, nutrient transporters, tight junction proteins, and cytokines by performing quantitative real-time (qRT)-PCR. The primer pair sequences used are shown in Table 3. NormFinder software (Andersen et al., 2004) was used to select the reference gene based on the lowest stability value $(A C T B ; 0.075$ and 0.113 in proximal jejunum and ileum tissue, respectively). The qRT-PCR was performed using a StepOnePlus Real-Time PCR System (Applied Biosystems) by the Genomics Facility at the University of Guelph (Guelph, Canada). To each well, $5 \mu \mathrm{L}$ of cDNA, $10 \mu \mathrm{L}$ of DNA polymerase-containing supermix (SsoAdvanced Universal Inhibitor-Tolerant SYBR Green, Bio-Rad), $0.8 \mu \mathrm{L}$ of $5 \mu M$ forward and reverse primer mix, and $4.2 \mu \mathrm{L}$ of nuclease-free $\mathrm{H}_{2} \mathrm{O}$ was added. The 2-step qPCR program consisted of 3 min at $98^{\circ} \mathrm{C}$, followed by 40 cycles of $10 \mathrm{~s}$ at $98^{\circ} \mathrm{C}$ and $30 \mathrm{~s}$ at $60^{\circ} \mathrm{C}$. Then, a melt curve was generated at $95^{\circ} \mathrm{C}$ for $15 \mathrm{~s}, 60^{\circ} \mathrm{C}$ for $1 \mathrm{~min}$, and $95^{\circ} \mathrm{C}$ for $15 \mathrm{~s}$ to confirm specificity of the PCR amplicon. The expression of the target gene relative to the reference gene was calculated according to Pfaffl (2001):

$$
\text { Ratio }=\frac{\mathrm{E}_{\text {target }}\left[\Delta \mathrm{Ct}_{\text {target }}(\text { control }- \text { sample })\right]}{\mathrm{E}_{\text {ref }}\left[\Delta \mathrm{Ct}_{\text {ref }}(\text { control }- \text { sample })\right]},
$$

where $\mathrm{E}_{\text {target }}$ and $\mathrm{E}_{\text {ref }}$ are the PCR efficiencies of the target and reference gene transcripts, respectively; and $\Delta C t_{\text {target }}$ and $\Delta \mathrm{Ct}_{\text {ref }}$ are the deviations in the number of cycles to exceed the threshold for background fluorescence between the control (average of HL group) and sample for the target gene and reference gene transcripts, respectively.

\section{Statistical Analysis}

All observations were analyzed using the GLIMMIX procedure of SAS software. We adjusted the response distribution in the model statement to log normal when it improved the fit of the model according to the distribution of studentized residuals and Shapiro-Wilk statistic. For data consisting of proportions (fractions of 1 ), a $\beta$ distribution was used. The model included the fixed effect of treatment and random effect of block. The experimental unit was the calf. For organ weights and lengths, birth BW was used as a covariate. For digesta osmolality data, segment was added to the aforementioned model as a fixed effect. Means were separated using the PDIFF statement of SAS software. For lactulose and D-mannitol concentrations in plasma, time and the interaction of treatment $\times$ time were included. The covariance structure used was unstructured, to allow for individual determination of the correlation between each of the time points. All values reported are least squares means \pm standard error of the mean, with significance declared at $P<0.05$ and tendencies at $0.05 \leq P<0.10$.

\section{RESULTS}

Effects of partially replacing lactose in MR with fat on feed intake, growth, abomasal emptying rate, and insulin sensitivity of the calves discussed in the current article were published previously (Welboren et al., 2021).

\section{Gastrointestinal Tract Weights and Lengths}

Effects of partially replacing lactose in MR with fat on GIT weights and lengths are presented in Table 4. We observed that the small intestine and total GIT were, respectively, 10 and $8 \%$ heavier in $\operatorname{HF}(P=0.014$ and $P=0.001$, respectively). Neither the weight of individual segments nor the length of the GIT differed between treatment groups.

\section{Digesta Osmolality}

Results on digesta osmolality are presented in Figure 1. No treatment or treatment $\times$ segment effect was observed; however, we observed a segment effect $(P$ $<0.001$ ) showing that digesta osmolality increases as digesta flows from the abomasum into the duodenum, decreases as the digesta transits through the small intestine, and plateaus when it reaches the large intestine.

\section{Gastrointestinal Permeability}

Indicators of gastrointestinal permeability are presented in Figure 2. Recovery of D-mannitol and lactulose in urine did not differ between treatment groups $(P$ $>0.490)$. Recovery of lactulose in plasma was increased $(P=0.004)$ in HF compared with HL calves, whereas 
Table 3. Genes analyzed in proximal jejunum and ileum tissue and primer pair sequences used (n/a = not applicable)

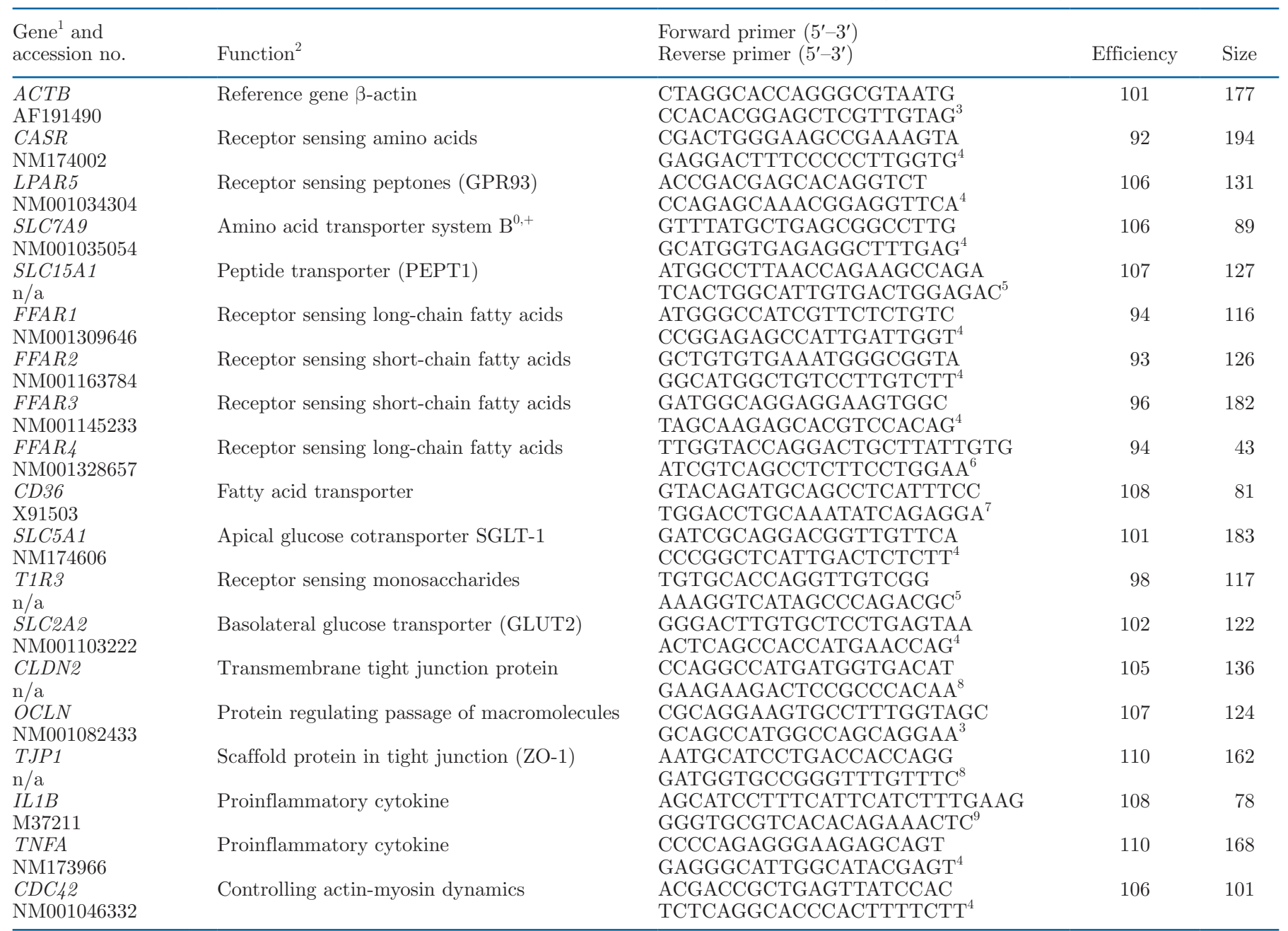

${ }^{1} A C T B=\beta$-actin, $C A S R=$ calcium sensing receptor, $L P A R 5=$ lysophosphatidic acid receptor $5, S L C 7 A 9=$ solute carrier family 7 member 9 , $S L C 15 A 1=$ solute carrier family 15 member $1, F F A R 1$ to FFAR $4=$ free fatty acid receptor 1 to $4, C D 36=$ cluster of differentiation $36, S L C 5 A 1$ $=$ solute carrier family 5 member $1, T 1 R 3=$ taste receptor type 1 member $3, S L C 2 A 2=$ solute carrier family 2 member $2, C L D N 2=$ claudin- 2 , $O C L N=$ occludin, $T J P 1=$ tight junction protein $1, I L 1 B=$ interleukin $1 \beta, T N F A=$ tumor necrosis factor $\alpha, C D C 42=$ cell division cycle 42 . ${ }^{2}$ Raybould, 2008; Miyauchi et al., 2010; Rasoamanana et al., 2012; Furness et al., 2013; Krug et al., 2014; Quiros and Nusrat, 2014; Spreckly and Murphy, 2015; Rohr et al., 2019.

${ }^{3}$ Malmuthuge et al., 2013.

${ }^{4}$ Current study.

${ }^{5}$ Fan et al., 2020.

${ }^{6}$ Agrawal, 2016.

${ }^{7}$ Bionaz and Loor, 2008.

${ }^{8}$ Walker et al., 2015.

${ }^{9}$ Galvão et al., 2011.

recovery of D-mannitol in plasma did not differ between treatment groups $(P=0.205)$.

\section{Histomorphology}

Results for histomorphology are presented in Table 5 . We observed that the HF treatment presented smaller $(P=0.040)$ duodenal villus height:crypt depth ratio and tended $(P=0.054)$ to have thinner villi. In addition, HF feeding tended to have greater crypt depth in the duodenum $(P=0.094)$ and crypt width in the proximal jejunum $(P=0.076)$. Furthermore, the HF treatment presented $13 \%$ shorter villi $(P=0.012), 21 \%$ lower villus height:crypt depth ratio $(P=0.034)$, and $14 \%$ lower surface area index $(P=0.039)$ in the ileum. The muscularis externa of colon tissue was $26 \%$ thinner 
in $\operatorname{HF}(P=0.012)$. We did not observe a treatment effect on any of the other variables measured.

\section{Gene Expression}

Effects on gene expression in proximal jejunum and ileum tissues are presented in Figures 3 and 4 . We found that the HF treatment tended to result in lower expression of $S L C 15 A 1(P=0.076)$ and FFAR1 $(P=$ $0.066)$ in proximal jejunum tissue, and $S L C 15 A 1(P=$ $0.087)$, SLC5A1 $(P=0.077)$, and T1R3 $(P=0.077)$ in ileum tissue. Furthermore, expression of $C L D N 2(P$ $=0.076)$ and TJP1 $(P=0.086)$ tended to be lower, and that of $I L 1 B(P=0.093)$ higher in ileum tissue of HF compared with HL calves. The expression of other genes analyzed was unaffected by MR treatment.

\section{DISCUSSION}

The recent shift to feeding calves more MR with little consideration for its macronutrient composition may negatively influence intestinal development and function in neonatal calves. In an attempt to bring the macronutrient composition of MR closer to that of whole milk by partially replacing lactose in MR with fat, we demonstrated that this resulted in greater GIT weight. Gastrointestinal tract weight is an indicator of gut growth and is regulated by chemical and physical dietary factors, as well as metabolic and trophic hormones (Baldwin et al., 2004). The heavier GIT in response to feeding HF could indicate a greater capacity to digest and absorb nutrients, although a larger GIT could also increase energetic cost to maintain the additional tissue mass (Naya et al., 2008). It is possible that for a growing neonate the increased capacity to digest and absorb nutrients outweighs the increased maintenance cost. Gastrointestinal tract size can be affected by intake because of altered energy requirements, such as the swift increase in GIT size of a lactating animal (Campbell and Fell, 1964). It is important to note that the diets in the current study were not isocaloric $(8 \%$ difference in ME intake), which may have affected GIT growth (McLeod and Baldwin, 2000; Baldwin et al., 2004). For instance, the GIT of weanling lambs fed at $200 \%$ of energy requirements for maintenance for approximately 52 d was $35 \%$ heavier per unit of BW than that of lambs fed at $100 \%$ of energy requirements for maintenance (McLeod and Baldwin, 2000). The increase in intestinal mass was due to increased cellularity with constant cell size and resulted in increased length, as well as smooth muscle and epithelial tissue mass (McLeod and Baldwin, 2000). However, in dairy calves fed $0.44(20.9 \%$ CP, $19.8 \%$ crude fat; approximately $75 \%$ of energy for maintenance) versus $1.02(28.9 \%$ CP, $26.2 \%$ crude fat; approximately $150 \%$ of energy for maintenance) kilograms of powder per day for $8 \mathrm{wk}$,

Table 4. Least squares means of weights and lengths of the gastrointestinal tract of neonatal dairy calves fed a high-lactose $(\mathrm{n}=17)$ or high-fat $(\mathrm{n}=17)$ milk replacer until $7 \mathrm{~d}$ of age

\begin{tabular}{|c|c|c|c|c|c|}
\hline \multirow[b]{2}{*}{ Item } & \multicolumn{2}{|c|}{ Milk replacer ${ }^{1}$} & \multirow[b]{2}{*}{ SEM } & \multirow[b]{2}{*}{$\begin{array}{l}P \text {-value of } \\
\text { treatment }\end{array}$} & \multirow[b]{2}{*}{$\begin{array}{c}P \text {-value of } \\
\text { BW }\end{array}$} \\
\hline & $\begin{array}{l}\text { High } \\
\text { lactose }\end{array}$ & $\begin{array}{l}\text { High } \\
\text { fat }\end{array}$ & & & \\
\hline \multicolumn{6}{|l|}{ 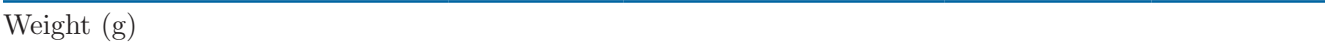 } \\
\hline Abomasum and omasum & 331.6 & 343.8 & 9.40 & 0.384 & 0.002 \\
\hline Reticulorumen & 209.2 & 208.3 & 6.21 & 0.924 & 0.006 \\
\hline Duodenum & 9.9 & 9.7 & 0.78 & 0.824 & 0.280 \\
\hline Jejunum & 673.8 & 724.0 & 29.89 & 0.269 & 0.325 \\
\hline Ileum & 261.1 & 290.2 & 16.35 & 0.239 & 0.017 \\
\hline Colon & 197.8 & 215.3 & 8.79 & 0.170 & 0.062 \\
\hline Rectum & 34.2 & 36.6 & 3.83 & 0.727 & 0.437 \\
\hline Small intestine ${ }^{2}$ & 953.7 & $1,052.0$ & 25.41 & 0.013 & 0.014 \\
\hline Total GIT ${ }^{3}$ & $1,727.3$ & $1,865.8$ & 34.36 & 0.011 & 0.001 \\
\hline \multicolumn{6}{|l|}{ Length (cm) } \\
\hline Jejunum & $1,409.5$ & $1,387.7$ & 51.66 & 0.780 & 0.140 \\
\hline Ileum & 401.5 & 464.6 & 35.09 & 0.183 & 0.097 \\
\hline Colon & 244.3 & 247.9 & 10.18 & 0.843 & 0.019 \\
\hline Small intestine ${ }^{4}$ & $1,827.3$ & $1,877.4$ & 49.97 & 0.534 & 0.006 \\
\hline Total intestine ${ }^{5}$ & $2,071.7$ & $2,125.3$ & 55.25 & 0.564 & 0.003 \\
\hline
\end{tabular}

${ }^{1}$ Sloten B.V., Trouw Nutrition. High lactose $=46.1 \%$ lactose and $18.0 \%$ fat on DM basis; high fat $=39.9 \%$ lactose and $24.6 \%$ fat on a DM basis.

${ }^{2}$ Small intestine $=$ duodenum + jejunum + ileum.

${ }^{3}$ Total gastrointestinal tract $($ GIT $)=$ abomasum and omasum + reticulorumen + small intestine + colon + rectum.

${ }^{4}$ Small intestine $=$ jejunum + ileum.

${ }^{5}$ Total intestine $=$ jejunum + ileum + colon. 
no difference in GIT weight per unit of BW was found (Geiger et al., 2016). To understand the implications of the heavier GIT of HF calves, we examined whether the GIT structure and function were affected.

Because GIT length was unaffected in the current study, it is possible that the difference in GIT weight originated from the tissue layers. The histomorphology data showed only minor changes throughout the GIT. However, we measured 10 villi per segment, and potentially a higher number of measurements per segment is required to improve the quality of the histomorphometrical analyses and reveal differences in histomorphology between treatments (Bühler et al., 1998). Potentially, the high-fat MR promoted intestinal mucosal hyperplasia, as observed in adult rats (Maxton et al., 1989). Increasing dietary fat in isocaloric diets from 1 to $50 \%$ of caloric requirements from an essential or saturated fatty acid mixture stimulated mucosal hyperplasia, resulting in increased mucosal weights throughout the small intestine without affecting its length (Maxton et al., 1989). Interestingly, the essential fatty acid mixture that these authors used contained safflower oil, which is rich in linoleic acid, and the saturated fatty acid mixture consisted predominantly of coconut oil. The fat mixture of the MR in the current study consisted of one-third coconut oil and also contained linoleic acid from palm oil (approximately 7\% of MR fat; Gee, 2007; Bhatnagar et al., 2009). Maxton et al. (1989) suggested that fat has a trophic action, possibly through the release of pancreaticobiliary peptides and gut peptides such as GLP-1 and GLP-2. Gut peptides are released by enteroendocrine cells in response to luminal nutrients (Furness et al., 2013). Nutrients can stimulate the release of gut peptides directly, by binding to a nutrient-sensing receptor on the plasma membrane of enteroendocrine cells, or indirectly, by activating the enteric nervous system (Brubaker and Anini, 2003; Rasoamanana et al., 2012; Furness et al., 2013).

Regarding direct nutrient stimulation, it is worth mentioning that fat transits to more distal regions of the GIT compared with products of protein and carbohydrate digestion, which may increase exposure to nutrient-sensing receptors throughout the GIT (Brubaker and Anini, 2003). This may suggest that the high-fat MR induced greater gut peptide secretion, resulting in increased GIT growth. However, if this was the case, it

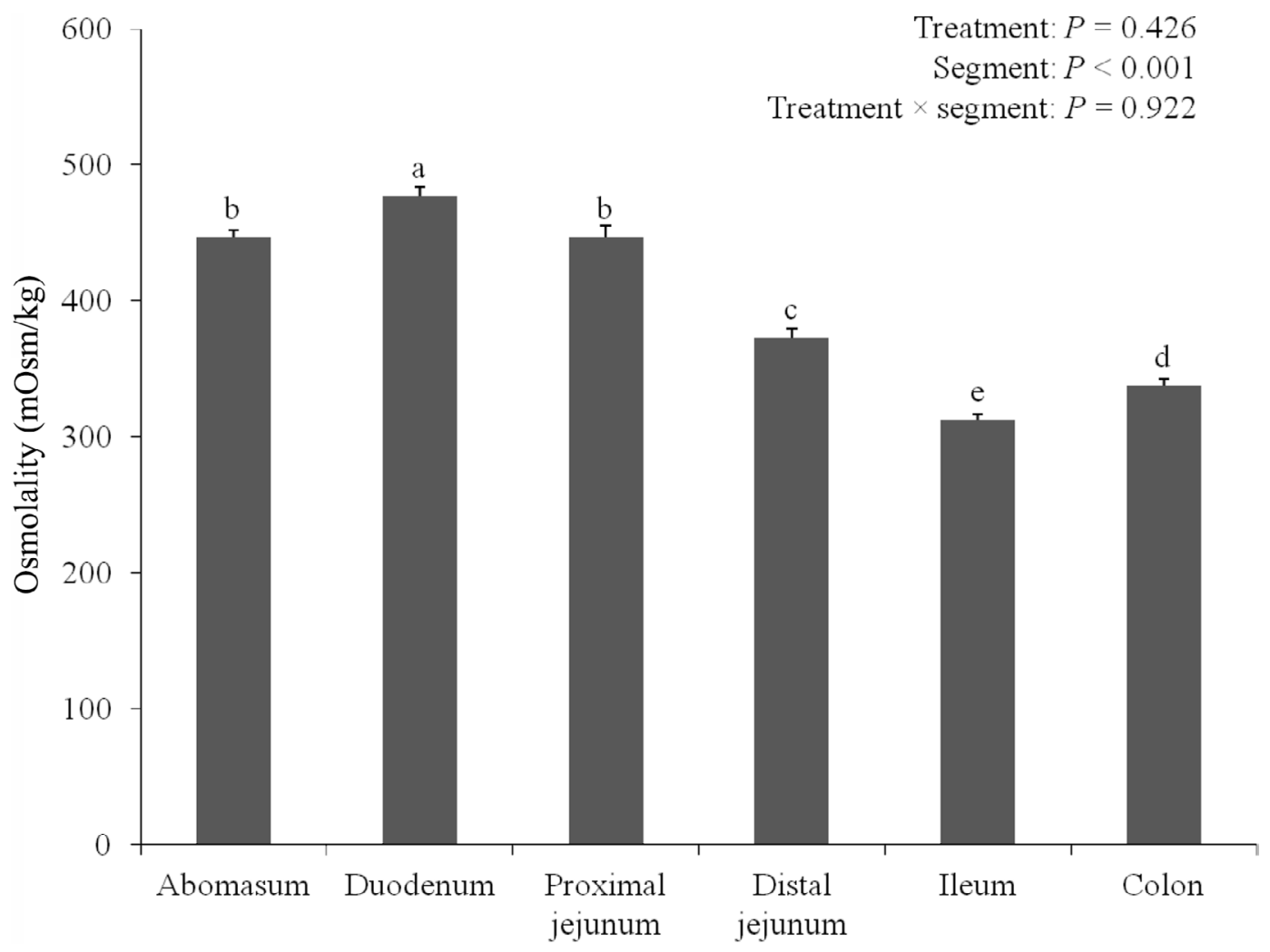

Figure 1. Least squares means \pm SEM of digesta osmolality in neonatal dairy calves fed a high-lactose $(46.1 \%$ lactose and $18.0 \%$ fat on DM basis; $\mathrm{n}=17)$ or high-fat $(39.9 \%$ lactose and $24.6 \%$ fat on DM basis; $\mathrm{n}=17)$ milk replacer until $7 \mathrm{~d}$ of age. Treatment and treatment $\times$ segment effects were nonsignificant $(P \geq 0.05)$, and therefore bars represent the data points of all calves. Segments without common letter differ $(P<0.05)$. 
did not increase the expression of genes coding for nutrient-sensing receptors in proximal jejunum and ileum tissue in HF calves. On the contrary, the expression of SLC15A1 and FFAR1 in proximal jejunum tissue, and SLC15A1, T1R3, and SLC5A1 in ileum tissue tended to be lower in HF calves. The tendencies for lower expression of T1R3 and SLC5A1 may have been caused by fewer luminal monosaccharides (Margolskee et al., 2007), whereas the tendencies for the other nutrientsensing and transporter genes in HF calves contrast with the hypothesis and therefore warrant further investigation. Potentially, the relatively high polyunsaturated fat content of the vegetable oils used as fat source for the MR may have altered the plasma membrane composition. Incorporation of polyunsaturated fatty acids into the plasma membrane can reduce or disrupt the lipid raft fraction, which contains proteins such as nutrient-sensing receptors and transporters (Ma et al., 2004; Shaikh, 2012).

Digesta osmolality was measured throughout the GIT to study its potential influence on gastrointestinal permeability. We did not observe differences in digesta osmolality between treatment groups, which could be due to the relatively small difference in MR osmolality $(33 \mathrm{mOsm} / \mathrm{kg})$. Moreover, the osmolalities of both MR were relatively high when compared with whole milk (280 mOsm $/ \mathrm{kg}$; Rozenfarb et al., 1997; Constable et al., 2009) and the WHO recommendation for maximum osmolality of infant formula (450 mOsm/kg; Pearson et al., 2013). Potentially, this may be caused by the relatively high mineral content of MR (7.8 vs. $4.0 \%)$ and the percentage of solids used (15.0 vs. $12.5 \%$ ) compared with whole milk (Moallem et al., 2010). Owen et al. (1958) demonstrated that a high level of dietary minerals, especially a mixture that simulated whey minerals (containing $\mathrm{Ca}, \mathrm{K}, \mathrm{Mg}, \mathrm{Na}$, and $\mathrm{Cl}$ ), caused diarrhea in preweaning calves. It is important to note that for the current study, different whey products were used to achieve formulations with different lactose contents. Therefore, the source of the minerals and ultimately their contribution to MR osmolality may differ between the MR treatments despite being formulated for a similar mineral profile. High osmolality of MR and GIT contents reduces the osmotic gradient for water absorption into the epithelium (Jodal and Lundgren, 1986), which may compromise intestinal health. We suggest
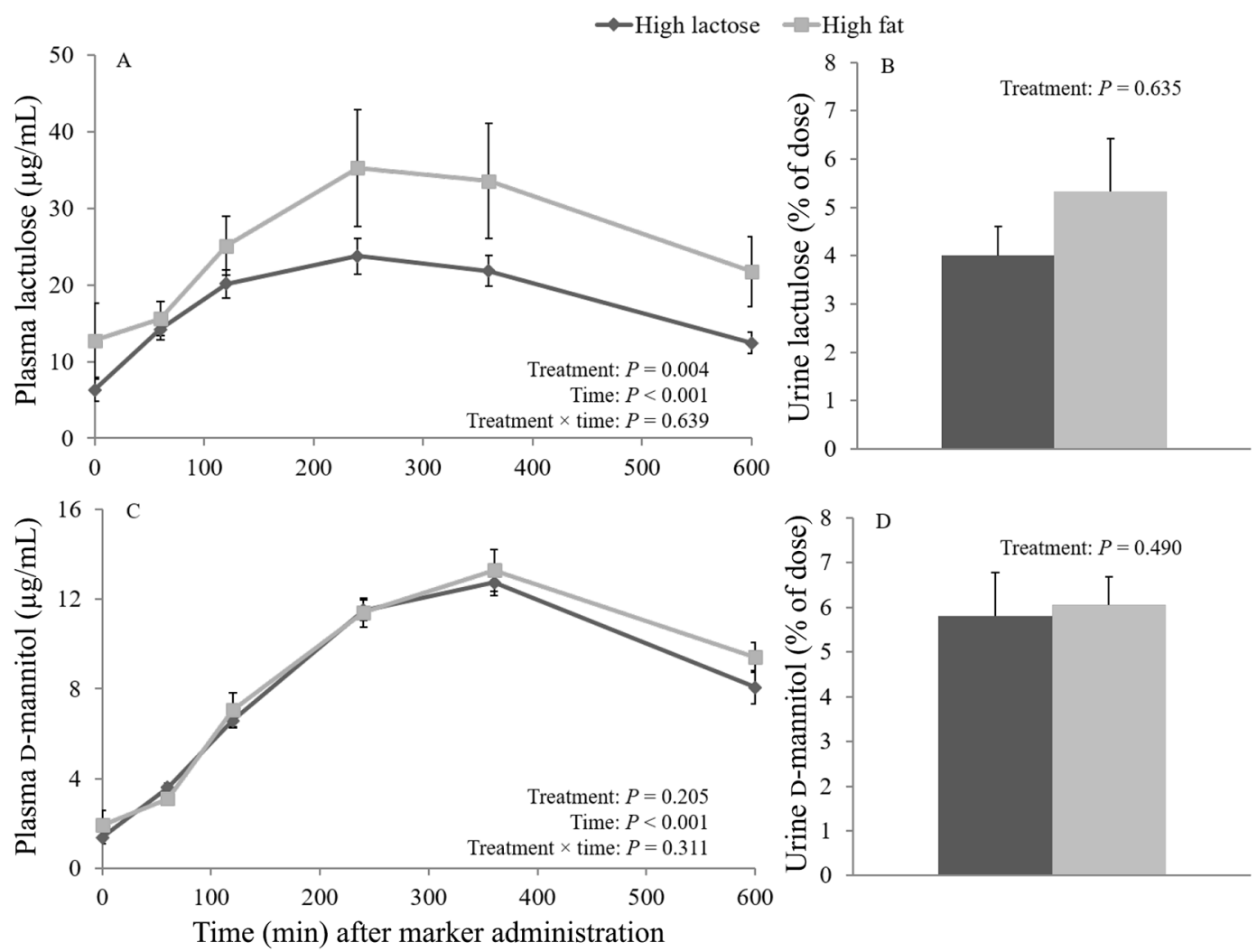

Figure 2. Means $\pm \mathrm{SE}$ of lactulose and D-mannitol content in plasma (A, C) and in urine collected for $12 \mathrm{~h}(\mathrm{~B}, \mathrm{D})$ of dairy calves fed a high-lactose $(46.1 \%$ lactose and $18.0 \%$ fat on DM basis; $\mathrm{n}=17)$ or high-fat $(39.9 \%$ lactose and $24.6 \%$ fat on DM basis; $\mathrm{n}=17) \mathrm{milk}$ replacer until $7 \mathrm{~d}$ of age. 
Table 5. Least squares means of histomorphology of neonatal dairy calves fed a high-lactose $(\mathrm{n}=17)$ or highfat $(\mathrm{n}=17)$ milk replacer until $7 \mathrm{~d}$ of age

\begin{tabular}{|c|c|c|c|c|}
\hline \multirow[b]{2}{*}{ Item $^{1}$} & \multicolumn{2}{|c|}{ Milk replacer $^{2}$} & \multirow[b]{2}{*}{ SEM } & \multirow[b]{2}{*}{$P$-value } \\
\hline & High lactose & High fat & & \\
\hline \multicolumn{5}{|l|}{ Duodenum } \\
\hline Villus height & 309.5 & 282.1 & 22.22 & 0.215 \\
\hline Villus width & 125.5 & 116.6 & 4.18 & 0.054 \\
\hline Crypt depth & 375.8 & 420.9 & 16.90 & 0.094 \\
\hline Crypt width & 56.0 & 57.1 & 1.79 & 0.619 \\
\hline Muscularis externa & 515.5 & 493.6 & 34.28 & 0.495 \\
\hline Villus height:crypt depth & 0.87 & 0.69 & 0.066 & 0.040 \\
\hline Surface area index & 5.26 & 4.98 & 0.367 & 0.497 \\
\hline \multicolumn{5}{|l|}{ Proximal jejunum } \\
\hline Villus height & 419.3 & 398.2 & 25.49 & 0.578 \\
\hline Villus width & 110.2 & 114.4 & 5.53 & 0.434 \\
\hline Crypt depth & 276.5 & 302.3 & 20.32 & 0.310 \\
\hline Crypt width & 43.7 & 47.6 & 2.35 & 0.076 \\
\hline Muscularis externa & 243.4 & 237.1 & 17.67 & 0.793 \\
\hline Villus height:crypt depth & 1.61 & 1.42 & 0.128 & 0.290 \\
\hline Surface area index & 8.37 & 7.44 & 0.522 & 0.182 \\
\hline \multicolumn{5}{|l|}{ Distal jejunum } \\
\hline Villus height & 391.6 & 375.5 & 27.36 & 0.628 \\
\hline Villus width & 98.1 & 98.2 & 4.70 & 0.994 \\
\hline Crypt depth & 305.0 & 300.00 & 18.10 & 0.864 \\
\hline Crypt width & 40.2 & 43.8 & 1.50 & 0.169 \\
\hline Muscularis externa & 245.8 & 251.7 & 15.49 & 0.805 \\
\hline Villus height:crypt depth & 1.36 & 1.33 & 0.106 & 0.826 \\
\hline Surface area index & 8.64 & 7.81 & 0.457 & 0.212 \\
\hline \multicolumn{5}{|l|}{ Ileum } \\
\hline Villus height & 469.9 & 406.6 & 23.22 & 0.012 \\
\hline Villus width & 119.8 & 115.9 & 5.51 & 0.585 \\
\hline Crypt depth & 289.5 & 315.1 & 15.18 & 0.166 \\
\hline Crypt width & 53.5 & 55.7 & 1.73 & 0.401 \\
\hline Muscularis externa & 264.5 & 268.0 & 18.49 & 0.877 \\
\hline Villus height:crypt depth & 1.74 & 1.38 & 0.112 & 0.034 \\
\hline Surface area index & 8.02 & 6.92 & 0.365 & 0.039 \\
\hline \multicolumn{5}{|l|}{ Colon } \\
\hline Mucosal thickness & 455.4 & 483.7 & 19.75 & 0.365 \\
\hline Muscularis externa & 733.9 & 545.6 & 43.16 & 0.012 \\
\hline
\end{tabular}

${ }^{1}$ Measurements in $\mu \mathrm{m}$.

${ }^{2}$ Sloten B.V., Trouw Nutrition. High lactose $=46.1 \%$ lactose and $18.0 \%$ fat on DM basis; high fat $=39.9 \%$ lactose and $24.6 \%$ fat on a DM basis.

that nutrient digestion caused the greater osmolality of the duodenum compared with abomasum digesta, since digestive breakdown increases the molar concentration of solutes. The subsequent decrease in digesta osmolality between the duodenum and ileum is likely due to absorption of dissolved nutrients. Because digesta osmolality between treatment groups did not differ, this indicates that osmolality is unlikely a factor involved in the observed difference in gastrointestinal permeability.

Our finding that high-fat MR increases gastrointestinal permeability is in agreement with a previous study conducted in preweaning calves using the same MR and the same marker administration protocol (Amado et al., 2019). The authors found a 1.5-fold increase in lactulose recovery in urine of HF compared with HL calves, and recovery of D-mannitol in urine was similar. Lactulose is a relatively large molecule (339 Da), and its limited absorption is understood to take place through the intercellular space. The increased paracellular permeability in HF calves may indicate that intestinal barrier function was compromised, allowing microorganisms and toxins to pass the intestinal barrier (Bjarnason et al., 1995; Bischoff et al., 2014). However, Amado et al. (2019) speculated that the increased marker recovery could have been due to an interaction with MR fat, as the markers were added to the MR meal-because, in studies with humans and piglets, it is more common to administer the markers after an overnight fast (Miele et al., 2009; Zhang and Guo, 2009; Kato et al., 2017). In the current study, the markers were also added to the MR meal, which may have affected marker recovery. Moreover, the HF MR slowed down abomasal emptying (Welboren et al., 2021), and it is currently unknown whether this influences marker recovery. More research 


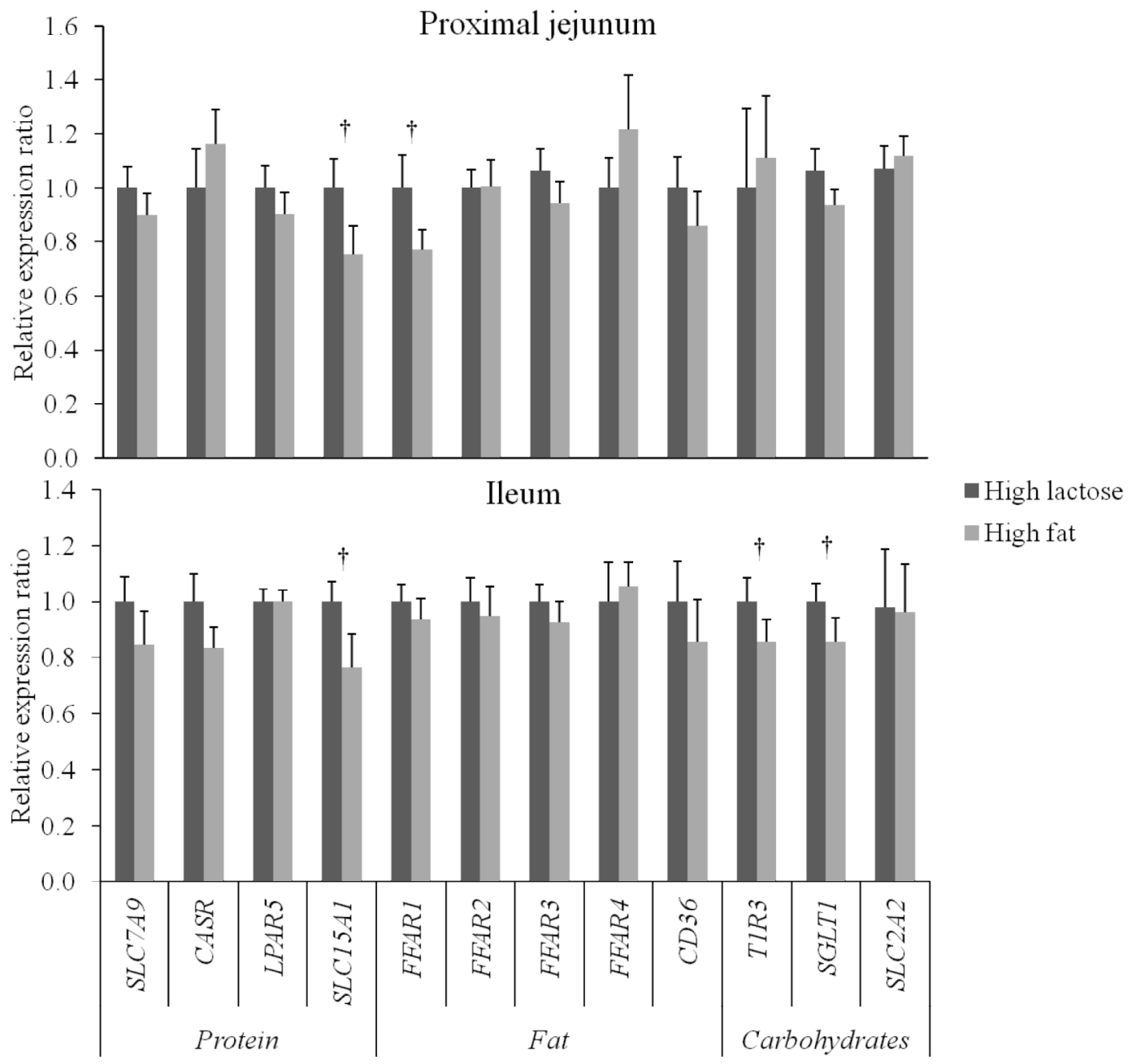

Figure 3. Least squares means \pm SEM of relative expression ratio of genes related to nutrient (protein, fat, or carbohydrate) sensing and transport in proximal jejunum and ileum tissue of neonatal dairy calves fed a high-lactose $(46.1 \%$ lactose and $18.0 \%$ fat on DM basis; $\mathrm{n}=17)$ or high-fat $(39.9 \%$ lactose and $24.6 \%$ fat on DM basis; $\mathrm{n}=17)$ milk replacer until $7 \mathrm{~d}$ of age. $\dagger P<0.10$.

is required to determine which methodology is most appropriate to study the influence of MR composition on gastrointestinal permeability.

However, the finding that dietary fat results in greater gastrointestinal permeability has been previously described. In rodents, increasing dietary fat from 12 to $72 \%$ or from 7 to $30 \%$ increased paracellular permeability due to lower expression of genes coding for tight junction proteins TJP1, CLDN1, and OCLN in intestinal epithelium (Cani et al., 2008; Suzuki and Hara, 2010). This coincides with our finding that expression of CLDN2 and TJP1 tended to be lower in the ileum tissue of HF calves. Lower expression of tight junction proteins in response to an $\mathrm{HF}$ diet could be the consequence of a modulation in gut microbiota (Cani et al., 2008; Moreira et al., 2012; Rohr et al., 2019). In healthy rodents, an HF diet reduces the abundance of gut barrier-promoting microbes, such as Lactobacillus spp. and Bifidobacterium spp. (both gram-positive), and increases the abundance of gut barrier-disrupting microbes, such as Desulfovibrio spp. (gram-negative). Consequently, intestinal permeation of LPS (membrane component of gram-negative bacteria) increases due to the greater abundance of LPS-containing bacteria. Then, incorporation of LPS into chylomicrons via its lipid A tail facilitates delivery to the circulatory system, resulting in endotoxemia (Ghoshal et al., 2009). Moreover, chylomicron synthesis is likely enhanced in response to an HF diet. Subsequent binding of LPS to toll-like receptor-4 and activation of the NF-KB pathway reduces tight junction protein expression and initiates an inflammatory response (Cani et al., 2008; Moreira et al., 2012).

Interestingly, expression of proinflammatory cytokine IL-1 $\beta$ tended to be greater in the ileum tissue of HF calves, which may indicate that more IL-1 $\beta$ was pro- 

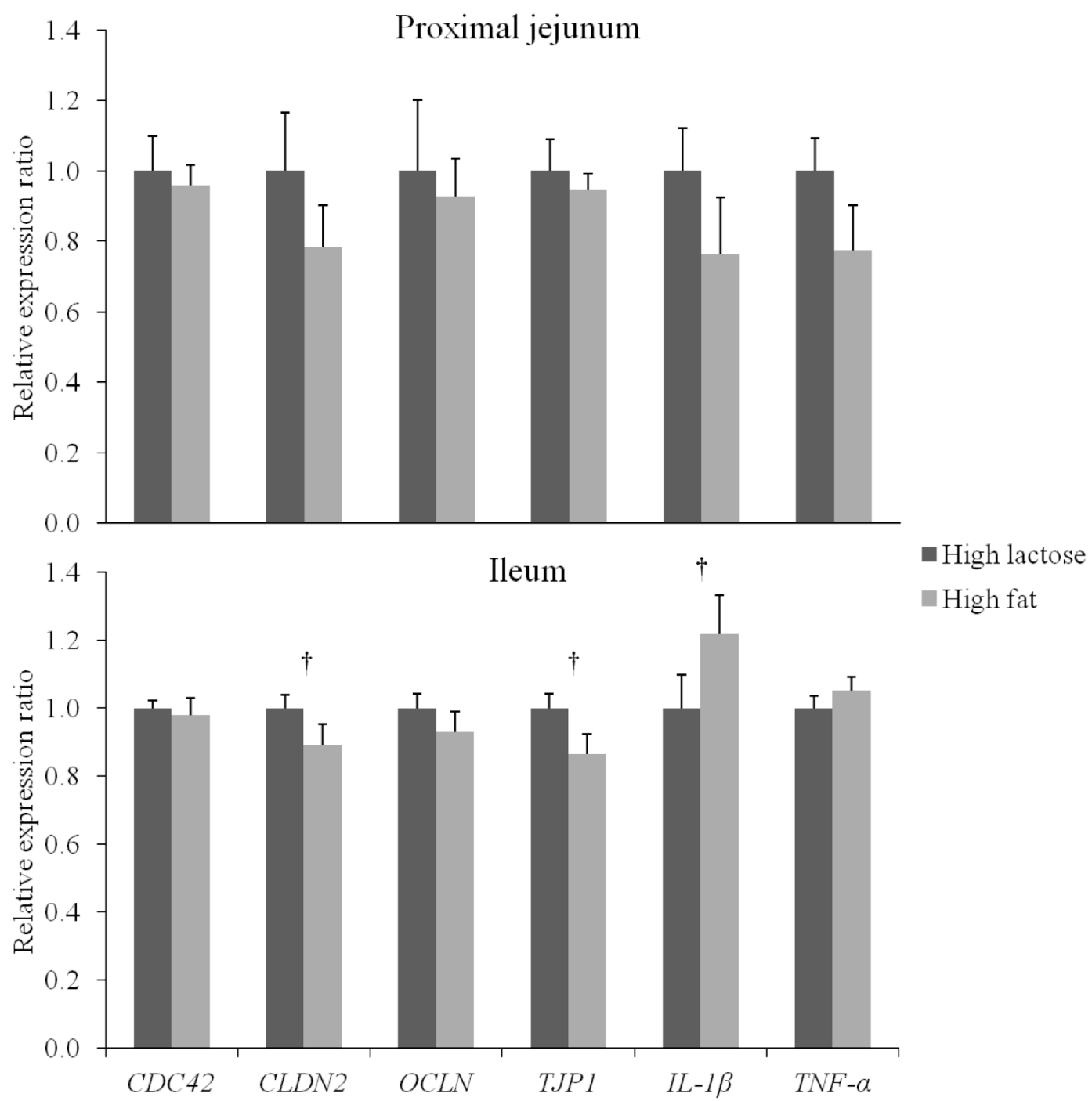

Figure 4. Least squares means \pm SEM of relative expression ratio of genes related to tight junction integrity and cytokine synthesis in proximal jejunum and ileum tissue of dairy calves fed a high-lactose (46.1\% lactose and $18.0 \%$ fat on DM basis; $\mathrm{n}=17)$ or high-fat $(39.9 \%$ lactose and $24.6 \%$ fat on DM basis; $\mathrm{n}=17)$ milk replacer until $7 \mathrm{~d}$ of age. $\dagger P<0.10$.

duced and secreted by cells in the ileum (e.g., immune cells). This supports the idea that HF feeding may promote inflammation and coincides with the increased paracellular permeability observed in this group. The tendency for increased $I L 1 B$ expression in the ileum compared with proximal jejunum tissue may be due to the accumulation of immune cells in Peyer's patches in ileum tissue. However, it is important to note that the RNA expression data showed tendencies and no significant differences between treatment groups, and mean differences were relatively small. All tissue samples used were whole tissues, including the muscularis externa, potentially indicating the importance of using methods to fractionate tissue, such as mucosal scrap- ing, to evaluate the appropriate tissue layer (Gaginella et al., 1978).

The type of dietary fat may also play a role in its effect on gastrointestinal permeability (Rohr et al., 2019). Polyunsaturated fatty acids contain double bonds, which makes them prone to oxidation. Oxidized polyunsaturated fatty acids can lead to intracellular oxidative stress, oxidative damage to epithelial plasma membranes, and eventually apoptosis (Wang et al., 2000; Rohr et al., 2019). The fat sources used for the MR in the current study were coconut and palm oil; therefore, the polyunsaturated fat content is relatively high compared with whole milk $(7.0$ vs. $4.1 \%$ of fat; Markiewicz-Kęszycka et al., 2013). Therefore, we may 
speculate that the increased supply of dietary fat (especially polyunsaturated fatty acids) in HF calves could have resulted in greater oxidative damage to the intestinal epithelium, which subsequently increased gastrointestinal permeability. These results call for more research to evaluate how not only quantity but also fat characteristics may influence GIT structure and permeability in neonatal calves.

\section{CONCLUSIONS}

Partially replacing lactose in MR with fat resulted in greater GIT weight when accounting for birth BW in neonatal dairy calves during the first week of life, likely due to mucosal hyperplasia, whereas GIT length was unaffected. Furthermore, gastrointestinal permeability was increased, likely resulting from a reduction in tight junction protein expression. Overall, partially replacing lactose with fat to mimic the macronutrient composition of whole milk may benefit GIT development but may also impair gut barrier function. More research is required to further understand the role of fat quantity and quality on GIT development, histomorphology, and permeability in neonatal calves.

\section{ACKNOWLEDGMENTS}

The authors gratefully acknowledge the staff of the Dairy Research and Technology Centre (University of Alberta, Edmonton, AB, Canada) for their assistance with the animal experiment. The authors also thank the laboratory support provided by Jing Zhang (Genomics Facility, University of Guelph, Guelph, Canada) and Jaeju Yu (Department of Animal Biosciences, University of Guelph, Guelph, Canada), and the funding support provided by Alberta Milk (Edmonton, AB, Canada), BC Dairy Association (Burnaby, BC, Canada), Dairy Farmers of Manitoba (Winnipeg, MB, Canada), SaskMilk (Regina, SK, Canada), Trouw Nutrition (Boxmeer, the Netherlands), the Saskatoon Colostrum Co. Ltd. (Saskatoon, SK, Canada), Bayer (Leverkusen, Germany), Lallemand Animal Nutrition (Montreal, QC, Canada), Westgen (Abbotsford, BC, Canada), and the National Science and Engineering Research Council of Canada (Ottawa, ON, Canada). The authors have not stated any conflicts of interest.

\section{REFERENCES}

Agrawal, A. 2016. Nutritional modulation of the transcriptome in adipose, liver, and polymorphonuclear leukocytes in peripartal dairy cows. MS thesis. Department of Animal Sciences, University of Illinois, Champaign, IL.

Amado, L., H. Berends, L. N. Leal, J. Wilms, H. Van Laar, W. J. J. Gerrits, and J. Martín-Tereso. 2019. Effect of energy source in calf milk replacer on performance, digestibility, and gut permeability in rearing calves. J. Dairy Sci. 102:3994-4001. https://doi.org/10 .3168/jds.2018-15847.

Andersen, C. L., J. L. Jensen, and T. F. Ørntoft. 2004. Normalization of real-time quantitative reverse transcription-PCR data: A model-based variance estimation approach to identify genes suited for normalization, applied to bladder and colon cancer data sets. Cancer Res. 64:5245-5250. https://doi.org/10.1158/0008-5472 .CAN-04-0496.

Baldwin, R. L., K. R. McLeod, J. L. Klotz, and R. N. Heitmann. 2004. Rumen development, intestinal growth and hepatic metabolism in the pre- and postweaning ruminant. J. Dairy Sci. 87:E55-E65. https://doi.org/10.3168/jds.S0022-0302(04)70061-2.

Berends, H., H. van Laar, L. N. Leal, W. J. J. Gerrits, and J. MartínTereso. 2020. Effects of exchanging lactose for fat in milk replacer on ad libitum feed intake and growth performance in dairy calves. J. Dairy Sci. 103:4275-4287. https://doi.org/10.3168/jds.2019 $-17382$.

Bhatnagar, A. S., P. K. Prasanth Kumar, J. Hemavathy, and A. G. Gopala Krishna. 2009. Fatty acid composition, oxidative stability, and radical scavenging activity of vegetable oil blends with coconut oil. J. Am. Oil Chem. Soc. 86:991-999. https://doi.org/10 $.1007 / \mathrm{s} 11746-009-1435-\mathrm{y}$.

Bionaz, M., and J. J. Loor. 2008. Gene networks driving bovine milk fat synthesis during the lactation cycle. BMC Genomics 9:366. https://doi.org/10.1186/1471-2164-9-366.

Bischoff, S. C., G. Barbara, W. Buurman, T. Ockhuizen, J. D. Schulzke, M. Serino, H. Tilg, A. Watson, and J. M. Wells. 2014. Intestinal permeability-A new target for disease prevention and therapy. BMC Gastroenterol. 14:189. https://doi.org/10.1186/ s12876-014-0189-7.

Bjarnason, I., A. Macpherson, and D. Hollander. 1995. Intestinal permeability: An overview. Gastroenterology 108:1566-1581. https:// doi.org/10.1016/0016-5085(95)90708-4.

Brubaker, P. L., and Y. Anini. 2003. Direct and indirect mechanisms regulating secretion of glucagon-like peptide-1 and glucagon-like peptide-2. Can. J. Physiol. Pharmacol. 81:1005-1012. https://doi .org/10.1139/y03-107.

Bühler, C., H. Hammon, G. L. Rossi, and J. W. Blum. 1998. Small intestinal morphology in eight-day-old calves fed colostrum for different durations or only milk replacer and treated with long-R3insulin-like growth factor I and growth hormone. J. Anim. Sci 76:758-765. https://doi.org/10.2527/1998.763758x.

Campbell, R. M., and B. F. Fell. 1964. Gastro-intestinal hypertrophy in the lactating rat and its relation to food intake. J. Physiol. 171:90-97. https://doi.org/10.1113/jphysiol.1964.sp007363.

Cani, P. D., R. Bibiloni, C. Knauf, A. Waget, A. M. Neyrinck, N. M. Delzenne, and R. Burcelin. 2008. Changes in gut microbiota control metabolic endotoxemia-induced inflammation in high-fat diet-induced obesity and diabetes in mice. Diabetes 57:1470-1481. https://doi.org/10.2337/db07-1403.

CCAC. 1993. Guide to the care and use of experimental animals, 1993. Vol. 1. Canadian Council on Animal Care. https://ccac.ca/en/ standards/guidelines/general-guidelines.html.

Constable, P. D., W. Grünberg, and L. Carstensen. 2009. Comparative effects of two oral rehydration solutions on milk clotting, abomasal luminal $\mathrm{pH}$, and abomasal emptying rate in suckling calves. J. Dairy Sci. 92:296-312. https://doi.org/10.3168/jds.2008-1462.

Fan, W., S. Saito, and S. Matsumura. 2020. Expression of the Tas1r3 and Pept1 genes in the digestive tract of wagyu cattle. Transl. Anim. Sci. 4:txaa019. https://doi.org/10.1093/tas/txaa019.

Furness, J. B., L. R. Rivera, H. J. Cho, D. M. Bravo, and B. Callaghan. 2013. The gut as a sensory organ. Nat. Rev. Gastroenterol. Hepatol. 10:729-740. https://doi.org/10.1038/nrgastro.2013.180.

Gaginella, T. S., H. S. Mekhjian, and T. M. O'dorisio. 1978. Vasoactive intestinal peptide: Quantification by radioimmunoassay in isolated cells, mucosa, and muscle of the hamster intestine. Gastroenterology 74:718-721. https://doi.org/10.1016/0016-5085(78)90250-0.

Galvão, K. N., N. R. Santos, J. S. Galvão, and R. O. Gilbert. 2011. Association between endometritis and endometrial cytokine ex- 
pression in postpartum Holstein cows. Theriogenology 76:290-299. https://doi.org/10.1016/j.theriogenology.2011.02.006.

Gee, P. T. 2007. Analytical characteristics of crude and refined palm oil and fractions. Eur. J. Lipid Sci. Technol. 109:373-379. https:// doi.org/10.1002/ejlt.200600264.

Geiger, A. J., C. L. M. Parsons, R. E. James, and R. M. Akers. 2016. Growth, intake, and health of Holstein heifer calves fed an enhanced preweaning diet with or without postweaning exogenous estrogen. J. Dairy Sci. 99:3995-4004. https://doi.org/10.3168/jds .2015-10405.

Ghoshal, S., J. Witta, J. Zhong, W. De Villiers, and E. Eckhardt. 2009. Chylomicrons promote intestinal absorption of lipopolysaccharides. J. Lipid Res. 50:90-97. https://doi.org/10.1194/jlr M800156-JLR200.

Hof, G. 1980. An investigation into the extent to which various dietary components, particularly lactose, are related to the incidence of diarrhoea in milk-fed calves. PhD dissertation. Department of Agricultural Sciences, Wageningen University, Wageningen, the Netherlands.

Jodal, M., and O. Lundgren. 1986. Countercurrent mechanisms in the mammalian gastrointestinal tract. Gastroenterology 91:225-241. https://doi.org/10.1016/0016-5085(86)90463-4.

Kameda, H., T. Abei, S. Nasrallah, and F. L. Iber. 1968. Functional and histological injury to intestinal mucosa produced by hypertonicity. Am. J. Physiol. 214:1090-1095. https://doi.org/10.1152/ ajplegacy.1968.214.5.1090.

Kato, T., Y. Honda, Y. Kurita, A. Iwasaki, T. Sato, T. Kessoku, S. Uchiyama, Y. Ogawa, H. Ohkubo, T. Higurashi, T. Yamanaka, H. Usuda, K. Wada, and A. Nakajima. 2017. Lubiprostone improves intestinal permeability in humans, a novel therapy for the leaky gut: A prospective randomized pilot study in healthy volunteers. PLoS One 12:e0175626. https://doi.org/10.1371/journal .pone. 0175626 .

Khan, M. A., D. M. Weary, and M. A. G. Von Keyserlingk. 2011. Invited review: Effects of milk ration on solid feed intake, weaning, and performance in dairy heifers. J. Dairy Sci. 94:1071-1081. https://doi.org/10.3168/jds.2010-3733.

Kisielinski, K., S. Willis, A. Prescher, B. Klosterhalfen, and V. Schumpelick. 2002. A simple new method to calculate small intestine absorptive surface in the rat. Clin. Exp. Med. 2:131-135. https://doi.org/10.1007/s102380200018.

Krug, S. M., J. D. Schulzke, and M. Fromm. 2014. Tight junction, selective permeability, and related diseases. Semin. Cell Dev. Biol. 36:166-176. https://doi.org/10.1016/j.semcdb.2014.09.002.

Lee, H. J., M. A. Khan, W. S. Lee, S. H. Yang, S. B. Kim, K. S. Ki, H. S. Kim, J. K. Ha, and Y. J. Choi. 2009. Influence of equalizing the gross composition of milk replacer to that of whole milk on the performance of Holstein calves. J. Anim. Sci. 87:1129-1137. https: //doi.org/10.2527/jas.2008-1110.

Louveau, I., M. H. Perruchot, M. Bonnet, and F. Gondret. 2016. Invited review: Pre-and postnatal adipose tissue development in farm animals: From stem cells to adipocyte physiology. Animal 10:1839-1847. https://doi.org/10.1017/S1751731116000872.

Ma, D. W., J. Seo, K. C. Switzer, Y. Y. Fan, D. N. McMurray, J. R. Lupton, and R. S. Chapkin. 2004. n-3 PUFA and membrane microdomains: A new frontier in bioactive lipid research. J. Nutr. Biochem. 15:700-706. https://doi.org/10.1016/j.jnutbio.2004.08 .002 .

Malmuthuge, N., Y. Chen, G. Liang, L. A. Goonewardene, and L. L. Guan. 2015. Heat-treated colostrum feeding promotes beneficial bacteria colonization in the small intestine of neonatal calves. J. Dairy Sci. 98:8044-8053. https://doi.org/10.3168/jds.2015-9607.

Malmuthuge, N., M. Li, L. A. Goonewardene, M. Oba, and L. L. Guan. 2013. Effect of calf starter feeding on gut microbial diversity and expression of genes involved in host immune responses and tight junctions in dairy calves during weaning transition. J. Dairy Sci. 96:3189-3200. https://doi.org/10.3168/jds.2012-6200.

Margolskee, R. F., J. Dyer, Z. Kokrashvili, K. S. Salmon, E. Ilegems, K. Daly, E. L. Maillet, Y. Ninomiya, B. Mosinger, and S. P. Shirazi-Beechey. 2007. T1R3 and gustducin in gut sense sugars to regulate expression of $\mathrm{Na}^{+}$-glucose cotransporter 1. Proc. Natl.
Acad. Sci. USA 104:15075-15080. https://doi.org/10.1073/pnas 0706678104.

Markiewicz-Kęszycka, M., G. Czyżak-Runowska, P. Lipińska, and J. Wójtowski. 2013. Fatty acid profile of milk-A review. Bull. Vet. Inst. Pulawy 57:135-139. https://doi.org/10.2478/bvip-2013-0026.

Maxton, D. G., E. U. Cynk, A. P. Jenkins, and R. P. Thompson. 1989. Effect of dietary fat on the small intestinal mucosa. Gut 30:1252-1255. https://doi.org/10.1136/gut.30.9.1252.

McLeod, K. R., and R. L. Baldwin. 2000. Effects of diet forage: Concentrate ratio and metabolizable energy intake on visceral organ growth and in vitro oxidative capacity of gut tissues in sheep. J. Anim. Sci. 78:760-770. https://doi.org/10.2527/2000.783760x.

Miele, L., V. Valenza, G. La Torre, M. Montalto, G. Cammarota, R. Ricci, R. Masciana, A. Forgione, M. L. Gabrieli, G. Perotti, F. M. Vecchio, G. Rapaccini, G. Gasbarrini, C. P. Day, and A. Grieco. 2009. Increased intestinal permeability and tight junction alterations in nonalcoholic fatty liver disease. Hepatology 49:1877-1887. https://doi.org/10.1002/hep.22848.

Miyauchi, S., A. Hirasawa, A. Ichimura, T. Hara, and G. Tsujimoto. 2010. New frontiers in gut nutrient sensor research: Free fatty acid sensing in the gastrointestinal tract. J. Pharmacol. Sci. 112:19-24. https://doi.org/10.1254/jphs.09R09FM.

Moallem, U., D. Werner, H. Lehrer, M. Zachut, L. Livshitz, S. Yakoby, and A. Shamay. 2010. Long-term effects of ad libitum whole milk prior to weaning and prepubertal protein supplementation on skeletal growth rate and first-lactation milk production. J. Dairy Sci. 93:2639-2650. https://doi.org/10.3168/jds.2009-3007.

Moreira, A. P. B., T. F. S. Texeira, A. B. Ferreira, M. do Carmo Gouveia Peluzio, and R. de Cássia Gonçalves Alfenas. 2012. Influence of a high-fat diet on gut microbiota, intestinal permeability and metabolic endotoxaemia. Br. J. Nutr. 108:801-809. https:// doi.org/10.1017/S0007114512001213.

Naya, D. E., L. A. Ebensperger, P. Sabat, and F. Bozinovic. 2008. Digestive and metabolic flexibility allows female degus to cope with lactation costs. Physiol. Biochem. Zool. 81:186-194. https:// doi.org/10.1086/527453.

Owen, F. G., N. L. Jacobson, R. S. Allen, and P. G. Homeyer. 1958. Nutritional factors in calf diarrhea. J. Dairy Sci. 41:662-670. https: //doi.org/10.3168/jds.S0022-0302(58)90980-9.

Pantophlet, A. J., W. J. J. Gerrits, R. J. Vonk, and J. J. G. C. van den Borne. 2016. Substantial replacement of lactose with fat in a high-lactose milk replacer diet increases liver fat accumulation but does not affect insulin sensitivity in veal calves. J. Dairy Sci. 99:10022-10032. https://doi.org/10.3168/jds.2016-11524.

Pearson, F., M. J. Johnson, and A. A. Leaf. 2013. Milk osmolality: Does it matter? Arch. Dis. Child. Fetal Neonatal Ed. 98:F166F169. https://doi.org/10.1136/adc.2011.300492.

Pfaffl, M. W. 2001. A new mathematical model for relative quantification in real-time RT-PCR. Nucleic Acids Res. 29:45e. https://doi .org/10.1093/nar/29.9.e45.

Quiros, M., and A. Nusrat. 2014. RhoGTPases, actomyosin signaling and regulation of the epithelial Apical Junctional Complex. Semin. Cell Dev. Biol. 36:194-203. https://doi.org/10.1016/j.semcdb.2014 .09 .003 .

Rasoamanana, R., N. Darcel, G. Fromentin, and D. Tomé. 2012. Nutrient sensing and signalling by the gut. Proc. Nutr. Soc. London Royal College of Physicians 71:446-455. https://doi.org/10.1017/ S0029665112000110

Raybould, H. E. 2008. Nutrient sensing in the gastrointestinal tract: Possible role for nutrient transporters. J. Physiol. Biochem. 64:349-356. https://doi.org/10.1007/BF03174091.

Rohr, M. W., C. A. Narasimhulu, T. A. Rudeski-Rohr, and S. Parthasarathy. 2019. Negative effects of a high-fat diet on intestinal permeability: A review. Adv. Nutr. 11:77-91. https://doi.org/10 .1093/advances/nmz061.

Rozenfarb, N., A. Kupietzky, and Z. Shey. 1997. Milk and egg albumen are superior to human saliva in preserving human skin fibroblasts. Pediatr. Dent. 19:347-348.

Seifarth, C. C., J. Miertschischk, E. G. Hahn, and J. Hensen. 2004. Measurement of serum and plasma osmolality in healthy young 
humans-Influence of time and storage conditions. Clin. Chem. Lab. Med. 42:927-932. https://doi.org/10.1515/CCLM.2004.150.

Shaikh, S. R. 2012. Biophysical and biochemical mechanisms by which dietary N-3 polyunsaturated fatty acids from fish oil disrupt membrane lipid rafts. J. Nutr. Biochem. 23:101-105. https://doi.org/ 10.1016/j.jnutbio.2011.07.001.

Soberon, F., and M. E. Van Amburgh. 2013. Lactation Biology Symposium: The effect of nutrient intake from milk or milk replacer of preweaned dairy calves on lactation milk yield as adults: A meta-analysis of current data. J. Anim. Sci. 91:706-712. https:// doi.org/10.2527/jas.2012-5834.

Spreckley, E., and K. G. Murphy. 2015. The L-cell in nutritional sensing and the regulation of appetite. Front. Nutr. 2:23. https://doi .org/10.3389/fnut.2015.00023.

Suzuki, T., and H. Hara. 2010. Dietary fat and bile juice, but not obesity, are responsible for the increase in small intestinal permeability induced through the suppression of tight junction protein expression in LETO and OLETF rats. Nutr. Metab. (Lond.) 7:19. https://doi.org/10.1186/1743-7075-7-19.

Urie, N. J., J. E. Lombard, C. B. Shivley, C. A. Kopral, A. E. Adams, T. J. Earleywine, J. D. Olson, and F. B. Garry. 2018. Preweaned heifer management on US dairy operations: Part V. Factors associated with morbidity and mortality in preweaned dairy heifer calves. J. Dairy Sci. 101:9229-9244. https://doi.org/10.3168/jds 2017-14019.

Walker, M. P., C. M. Evock-Clover, T. H. Elsasser, and E. E. Connor. 2015. Glucagon-like peptide-2 and coccidiosis alter tight junction gene expression in the gastrointestinal tract of dairy calves. J. Dairy Sci. 98:3432-3437. https://doi.org/10.3168/jds.2014-8919.
Wang, T. G., Y. Gotoh, M. H. Jennings, C. A. Rhoads, and T. Y. Aw. 2000. Lipid hydroperoxide-induced apoptosis in human colonic CaCo-2 cells is associated with an early loss of cellular redox balance. FASEB J. 14:1567-1576. https://doi.org/10.1096/fj.99 $-0799 \mathrm{com}$.

Welboren, A. C., B. Hatew, O. López-Campos, J. P. Cant, L. N. Leal, J. Martín-Tereso, and M. A. Steele. 2021. Effects of energy source in milk replacer on glucose metabolism of neonatal dairy calves. J. Dairy Sci. 104:5009-5020. https://doi.org/10.3168/jds.2020-19405.

Wilms, J., H. Berends, and J. Martín-Tereso. 2019. Hypertonic milk replacers increase gastrointestinal permeability in healthy dairy calves. J. Dairy Sci. 102:1237-1246. https://doi.org/10.3168/jds .2018-15265.

Young, R. A. 1976. Fat, energy and mammalian survival. Am. Zool. 16:699-710. https://doi.org/10.1093/icb/16.4.699.

Zhang, B., and Y. Guo. 2009. Supplemental zinc reduced intestinal permeability by enhancing occludin and zonula occludens protein-1 (ZO-1) expression in weaning piglets. Br. J. Nutr. 102:687693. https://doi.org/10.1017/S0007114509289033.

\section{ORCIDS}

A. C. Welboren $\odot$ https://orcid.org/0000-0003-1403-2954

B. Hatew $\odot$ https://orcid.org/0000-0002-7235-716X

L. N. Leal $\odot$ https://orcid.org/0000-0002-7798-3995

J. Martín-Tereso (1) https://orcid.org/0000-0002-6757-4629

M. A. Steele $\odot$ https://orcid.org/0000-0001-6941-6205 